\title{
Kinetics of strontium uptake in the scleractinian coral Stylophora pistillata
}

\author{
Christine Ferrier-Pagèss ${ }^{1, *}$, Florence Boisson ${ }^{3}$, Denis Allemand ${ }^{1,2}$, Eric Tambutté ${ }^{1}$ \\ ${ }^{1}$ Centre Scientifique de Monaco, c/o Musée océanographique, Avenue Saint Martin, 98000 Monaco \\ ${ }^{2}$ Université de Nice-Sophia Antipolis, UMR UNSA-INRA 1112, Faculté des Sciences, Parc Valrose, 06108 Nice cedex 08 , France \\ ${ }^{3}$ IAEA Marine Environment Laboratory, 4 Quai Antoine $1^{\mathrm{er}}$, BP 800, 98012 cedex Monaco
}

\begin{abstract}
Reef-building corals are very sensitive to changes in their environment and have been identified as potential accurate recorders of environmental changes. They form aragonitic carbonate skeletons that contain relatively high amounts of strontium $\left(\mathrm{Sr}^{2+}\right)$. The ratio of $\mathrm{Sr}^{2+} /$ calcium $\left(\mathrm{Ca}^{2+}\right)$ has been proved to be useful for paleoclimatic studies since it has been suggested to vary with the seawater temperature. However, no correlation can be established between skeletal $\mathrm{Sr}^{2+}$ content and environmental parameters due to the lack of knowledge concerning the extent to which skeletal chemistry is controlled by physiological parameters. In this study, we investigated the pathway of $\mathrm{Sr}^{2+}$ incorporation by the scleractinian coral Stylophora pistillata. For this purpose, we used ${ }^{85} \mathrm{Sr}$ and a non-destructive $\mathrm{NaI} \gamma$ detector. $\mathrm{Sr}^{2+}$ skeletal incorporation was found to be linear during the 9 experimental days of incubation with natural concentrations of $\mathrm{Sr}^{2+}$. The incorporation of $\mathrm{Sr}^{2+}$ versus external $\mathrm{Sr}^{2+}$ concentration was also linear up to $3.42 \mathrm{mM}$ (i.e. a concentration 37.5 times higher than normal seawater concentration). However, the uptake of $\mathrm{Sr}^{2+}$ at high concentrations (>1 mM) decreased with an increase in $\mathrm{Ca}^{2+}$ concentration in the seawater. Moreover, Verapamil, a $\mathrm{Ca}^{2+}$ channel inhibitor, also inhibits the incorporation of $\mathrm{Sr}^{2+}$ with the same $\mathrm{I}_{\mathrm{c} 50}(12 \mu \mathrm{M})$ as for $\mathrm{Ca}^{2+}$. Incorporation of $\mathrm{Sr}^{2+}$ is therefore inversely correlated to the rate of calcification, suggesting interactions between these 2 ions, which should be taken into account during paleoclimatic studies.
\end{abstract}

KEY WORDS: Corals $\cdot$ Strontium $\cdot$ Calcium $\cdot$ Paleoclimatology

\section{INTRODUCTION}

Strontium $\left(\mathrm{Sr}^{2+}\right)$ is a relatively common constituent of seawater and one of the most abundant trace elements (8 $\mathrm{mg} \mathrm{l}^{-1}$ or $\left.91 \mu \mathrm{M}\right)$. It is chemically similar to calcium $\left(\mathrm{Ca}^{2+}\right)$ and is generally considered to substitute for $\mathrm{Ca}^{2+}$ in the aragonite lattice (Speer 1983) of biogenic carbonate (coral skeletons, mollusc shells, foraminifera and fish bones). The study of $\mathrm{Sr}^{2+}$ has several implications.

On one hand, radiostrontium can be very harmful to the environment because of its fission yield $\left({ }^{90} \mathrm{Sr}\right.$ and ${ }^{89} \mathrm{Sr}$ ), long half-life (ca. $20 \mathrm{yr}$ ) and accumulation in calcifying tissues. It is one of the major radioelements in the environment, whose level is checked and recorded

*Email: ferrier@centrescientifique.mc because high activity was found after the Chernobyl accident in 1986 (Matsunaga et al. 1997). It is also abundant in discharge waters from uranium mines (Nichols \& Scholz 1989) and nuclear installations (Spangenberg \& Cherr 1996, Noureddine \& Baggoura 1997) as well as being detected near oil and gas fields (Olsgard \& Gray 1995). Therefore, the processes involved in its incorporation in calcifying tissues are of particular interest.

On the other hand, scleractinian corals form aragonitic carbonate skeletons that also contain relatively high amounts of $\mathrm{Sr}^{2+}$ (Milliman 1974). The use of such corals as archives of ocean chemistry and physical properties is one of the most rapidly growing fields of chemical oceanography and paleoceanography (Druffel 1997). $\mathrm{Sr}^{2+}$ thermometry has been suggested to be a powerful tool for reconstructing seawater sur- 
face temperature and is based on an inverse relationship between water temperature and $\mathrm{Sr}^{2+} / \mathrm{Ca}^{2+}$ ratios (Weber 1973). Subsequent studies using mass spectrometry techniques also empirically correlated $\mathrm{Sr}^{2+} / \mathrm{Ca}^{2+}$ with temperature or a $\delta^{18} \mathrm{O}$ estimate of temperature (Swart 1981, Beck et al. 1992, McCullough et al. 1994, DeVilliers et al. 1995, Juillet-Leclerc et al. 1997, Evans et al. 1998), and good relationships were reported between these 2 parameters (Hughen et al. 1999, McCullough et al. 1999), with a precision of $\pm 0.5^{\circ} \mathrm{C}$ (Beck et al. 1992). Some studies however argued that the $\mathrm{Sr}^{2+} / \mathrm{Ca}^{2+}$ thermometer is wrought with problems because it was shown to vary widely between or within species (Allison 1996, Rosenthal et al. 1997), or to correlate well with coral extension rates (DeVilliers et al. 1994, 1995). It has also been found within a single Porites coral colony that low-density skeleton in depressed valleys had a higher mean $\mathrm{Sr}^{2+} / \mathrm{Ca}^{2+}$ value than the high-density skeleton on elevated bumps (Alibert \& McCulloch 1997). Finally, ion probe microanalyses across coral growth bands have revealed a heterogeneous distribution of $\mathrm{Sr}^{2+}$ that is inconsistent with temperature fluctuations (Hart \& Cohen 1996). Additionally, the mineral strontianite was also identified in some corals using X-ray analysis (Greegor et al. 1997). These observations all suggest that temperature is not the only factor controlling $\mathrm{Sr}^{2+} / \mathrm{Ca}^{2+}$ ratio in corals and that biological factors must also play a role (Hart \& Cohen 1996, Cohen et al. 2001). Therefore, no clear correlation could be established between skeletal $\mathrm{Sr}^{2+}$ content and environmental parameters due to the lack of knowledge concerning the extent to which skeletal chemistry is controlled by physiological parameters (Boiseau et al. 1997).

Few studies have investigated the kinetics of $\mathrm{Sr}^{2+}$ uptake by calcifying organisms. In molluscs, it was shown that $\mathrm{Sr}^{2+}$ was incorporated into the shells in direct proportion to its level in seawater (Hockett et al. 1997) and that organisms held in $\mathrm{Sr}^{2+}$-enriched seawater partially replaced $\mathrm{Ca}^{2+}$ in their shells by $\mathrm{Sr}^{2+}$ (Peck et al. 1996). However, Wansard et al. (1999) noticed that the incorporation of $\mathrm{Sr}^{2+}$ versus $\mathrm{Ca}^{2+}$ in ostracods also largely depended on the calcification processes involved, light-weight shells being depleted in $\mathrm{Sr}^{2+}$ content compared to well-calcified valves. Studies performed on corals also gave 2 opposite results for $\mathrm{Sr}^{2+}$ uptake. The first mechanism involved similar physiological processes for $\mathrm{Ca}^{2+}$ and $\mathrm{Sr}^{2+}$ uptake, with competition between these 2 elements (Goreau 1977 , Swart 1980, Chalker 1981). In this case, $\mathrm{Sr}^{2+}$ is supposed to be deposited via an active process. The second mechanism involved 2 transport systems (Ip \& Krishnaveni 1991, Ip \& Lim 1991), with discrimination between the 2 elements. In this case, the deposition of $\mathrm{Sr}^{2+}$ is supposed to be a diffusive process.
The aim of this study, therefore, is to improve our knowledge of the uptake kinetics of $\mathrm{Sr}^{2+}$ in the scleractinian coral Stylophora pistillata. For this purpose, corals were incubated with the radiotracer ${ }^{85} \mathrm{~S}$ in artificial seawater containing different $\mathrm{Ca}^{2+}$ and stable $\mathrm{Sr}^{2+}$ concentrations, and the transfer of radioactivity was followed in the different coral compartments. The $\mathrm{Ca}^{2+}$ channel inhibitor, Verapamil, was also tested for the $\mathrm{Sr}^{2+}$ uptake. An important advance in this research was the utilisation of a non-destructive method, allowing the measurement of $\mathrm{Sr}^{2+}$ incorporation into the skeleton.

\section{MATERIALS AND METHODS}

Biological material. Experiments were carried out in the laboratory with microcolonies (branch tips $1 \mathrm{~cm}$ long, $1 \mathrm{~cm}$ wide) of Stylophora pistillata (Esper 1797). Colonies were collected in the Gulf of Aqaba (Red Sea, Jordan) from $5 \mathrm{~m}$ depth and maintained in open flow aquaria. Microcolonies $(n=180)$ were prepared by cutting terminal portions of branches of 10 mother colonies with bone-cutting pliers as described earlier (Tambutté et al. 1995). They were then suspended with a nylon mesh in an aquarium supplied with oligotrophic Mediterranean seawater (pumped from $50 \mathrm{~m}$ depth and heated to $26^{\circ} \mathrm{C}$ ); $400 \mathrm{~W}$ metal halide lamps (Philips, HPIT) provided a constant irradiance of $180 \mu \mathrm{mol}$ photons $\mathrm{m}^{-2} \mathrm{~s}^{-1}$ on a 12:12 h light:dark regime. After approximately 1 mo of healing, tissue entirely recovered the exposed skeleton, and coral fragments were ready to be used for the uptake experiments. During the whole experiment, microcolonies were fed once a week with Artemia salina nauplii.

Experimental protocol. Kinetics of $\mathbf{S r}^{2+}$ uptake: To assess the rate of $\mathrm{Sr}^{2+}$ uptake as a function of time, 3 aquaria containing 201 of oxygenated seawater were prepared with 3 different concentrations of stable $\mathrm{Sr}^{2+}$, the lowest concentration being similar to the $\mathrm{Sr}^{2+}$ level of $8.1 \mathrm{mg} \mathrm{l}^{-1}$ observed in the marine environment (Horne 1969), i.e. 10, 20 and $50 \mathrm{mg} \mathrm{l}^{-1}$ (or 0.11, 0.23 and $0.57 \mathrm{mM}$ ) made up from a stock solution of strontium chloride. Seawater was then spiked in each aquarium with the radiotracer ${ }^{85} \mathrm{Sr}$ (carrier-free, obtained from LEA, $\mathrm{T}_{1 / 2}=64.85 \mathrm{~d}$ ) to reach an activity of $7.052 \mathrm{KBq}^{-1}$. Fifteen coral microcolonies were then randomly divided in each aquarium (5 per tank) and incubated under the same conditions of light and temperature as described above. The incubation medium was changed every $2 \mathrm{~d}$ both for the health of the corals and to maintain the ${ }^{85} \mathrm{Sr}$ activity at an approximately constant level. The ${ }^{85} \mathrm{Sr}$ uptake by corals was followed after 2,7 and then every $24 \mathrm{~h}$ over $9 \mathrm{~d}$ in the same microcolony and for the 5 colonies incubated in each 
tank (a total of 40 measurements for each $\mathrm{Sr}^{2+}$ concentration). At each sampling time, all microcolonies were processed as described below.

Process of $\mathrm{Sr}^{2+}$ uptake: The second set of experiments was designed to investigate the processes involved in the ${ }^{85} \mathrm{Sr}$ uptake in the coral tissue and skeleton. The first experiment was repeated but with a broader range of $\mathrm{Sr}^{2+}$ concentrations. Six 201 aquaria were spiked with $\mu \mathrm{l}$ quantities of the radiotracer ${ }^{85} \mathrm{Sr}$ solution to reach a final activity of $7.111 \mathrm{~Bq} \mathrm{l}^{-1}$. Stable $\mathrm{Sr}^{2+}$, prepared as above, was added to each aquarium to obtain concentrations of 10,20,30,50, 150 and $300 \mathrm{mg} \mathrm{l}^{-1}$ (or 0.11, 0.23, 0.34, 0.57, 1.71 and $3.43 \mathrm{mM}$, respectively). Thirty microcolonies were equally divided into the 6 tanks (5 per tank) and incubated for $3 \mathrm{~d}$ under the same conditions of light and temperature as previously described. At the end of the incubation, all corals were processed as described below to measure the amount of ${ }^{85} \mathrm{Sr}$ in the whole colony, tissues and skeleton. The amount of protein was also determined. The experiment was repeated twice.

The uptake of ${ }^{85} \mathrm{Sr}$ was also measured under different concentrations of Verapamil, a $\mathrm{Ca}^{2+}$ channel inhibitor (Tambutté et al. 1996). For this purpose, microcolonies were individually pre-incubated for $30 \mathrm{~min}$ in $50 \mathrm{ml}$ beakers containing: $0,1,5,10,50$ and $100 \mu \mathrm{M}$ Verapamil previously dissolved in dimethyl sulfoxide solution (DMSO, 0.1\%). Microcolonies were then transferred to another set of $50 \mathrm{ml}$ beakers spiked with $1.200 \mathrm{KBq} \mathrm{ml}{ }^{-1}$ of ${ }^{85} \mathrm{Sr}$ and the above concentrations of Verapamil, after which they were incubated for $1 \mathrm{~h}$. Three microcolonies were individually incubated at each Veramapil concentrations and were processed as described below at the end of the incubation to measure the amount of ${ }^{85} \mathrm{Sr}$ in the whole colony, tissues and skeleton.

$\mathbf{S r}^{2+}-\mathbf{C a}^{2+}$ interactions: The third set of experiments was performed to determine the interactions between $\mathrm{Sr}^{2+}$ and $\mathrm{Ca}^{2+}$ uptake. For this purpose, uptake of ${ }^{85} \mathrm{Sr}$ was measured under different $\mathrm{Ca}^{2+}$ concentrations in seawater. Corals were individually incubated for $2 \mathrm{~h}$ in a vial containing artificial seawater and 7 different $\mathrm{Ca}^{2+}$ concentrations $(0,1,3,7,10,15$ and $20 \mathrm{mM})$ and $\mu \mathrm{l}$ quantities of the radiotracer ${ }^{85} \mathrm{Sr}$ at a final activity of ca. $1.006 \mathrm{kBq} \mathrm{ml}^{-1}$. Four experiments were performed with 10,100, 200 and $400 \mathrm{mg} \mathrm{l}^{-1}$ of $\mathrm{Sr}^{2+}$ in seawater. Free artificial seawater (ASW) was prepared from distilled water (Allemand et al. 1984). $\mathrm{NaCl}$ replaced $\mathrm{CaCl}_{2}$ in order to maintain constant osmolarity. All chemicals (Sigma) were of analytical grade and did not contain $\mathrm{Sr}^{2+}$ in their composition (or in negligible quantity). At the end of the incubation, microcolonies were processed as described below. This experiment was performed with 1 microcolony for each $\mathrm{Ca}^{2+}$ and $\mathrm{Sr}^{2+}$ concentration and was repeated 3 times.
Sample processing: At each sampling time, microcolonies were rinsed with normal seawater, blotted dry on absorbent paper to eliminate any adhering radioactive medium and transferred to counting vials containing $50 \mathrm{ml}$ of seawater. $\gamma$-emission was counted for $5 \mathrm{~min}$. They were then placed back in their aquarium and the activity of the $50 \mathrm{ml}$ of counting medium was measured to evaluate ${ }^{85} \mathrm{Sr}$ loss during counting. This method is a non-destructive measurement of $\mathrm{Sr}^{2+}$ uptake, since coral microcolonies were not sacrificed for the measurement. At the end of the experiment, the whole colony was counted as described above. It was then incubated for $30 \mathrm{~min}$ in $50 \mathrm{ml}$ of seawater to measure the efflux, which is the amount of seawater contained in the coelenteric cavity of the corals (Tambutté et al. 1995). The time needed to complete the efflux procedure was determined in previous experiments (Tambutté et al. 1996) and it was shown that $30 \mathrm{~min}$ was sufficient to totally renew the coelenteric content. Upon completion of the efflux, tissues were dissolved for $20 \mathrm{~min}$ in $1 \mathrm{ml}$ of $1 \mathrm{~N} \mathrm{NaOH}$ at $90^{\circ} \mathrm{C} .{ }^{85} \mathrm{Sr}$ activity was determined in the tissue (also referred to as ' $\mathrm{NaOH}$ soluble pool') as well as in the skeleton. Protein concentrations were measured in the $\mathrm{NaOH}$ soluble pool on a Multiscan Bichromatic system (Labsystem) using the BC assay kit (uptima) with bovine serum albumin as the standard. Skeletons were dried, weighed and their ${ }^{85} \mathrm{Sr}$ activity was evaluated.

The $\gamma$-emission of ${ }^{85} \mathrm{Sr}(506 \mathrm{KeV})$ in the whole colony, skeleton, tissue and seawater was determined using 2 well type NaI detectors (3 inch) connected to a multichannel analyser and a computer using a spectral analysis software. The activity of samples was corrected for background, radioactive decay and counting efficiency, and was compared with standards of appropriate geometry. Counting times were adjusted to give the relative propagated error $<5 \%$ at the 1 SD level, i.e. $5 \mathrm{~min}$ for the whole colony and the skeleton, $20 \mathrm{~min}$ for the tissues and the efflux seawater.

Results concerning the incorporation of $\mathrm{Sr}^{2+}$ in the colony, tissue and skeleton, are expressed as nmol $\mathrm{l}^{-1}$ from $\mathrm{Bq} \mathrm{ml} \mathrm{m}^{-1}$ and specific radioactivity of the medium (for details see Tambutté et al. 1995).

\section{RESULTS}

Results obtained in the first experiment (Fig. 1) showed that the uptake of $\mathrm{Sr}^{2+}$ was linear as a function of time over an exposure period of $9 \mathrm{~d}$ at 3 different $\mathrm{Sr}^{2+}$ concentrations. The same results are obtained when data are normalised per mg protein or per $\mathrm{g}$ skeleton $\left(\mathrm{gCaCO}_{3}\right)$. The slope of the regression lines gave the following uptake rates respectively for 0.11 , 0.23 and $0.57 \mathrm{nM}$ of $\mathrm{Sr}^{2+}$ in seawater: $28.14,81.75$ and 


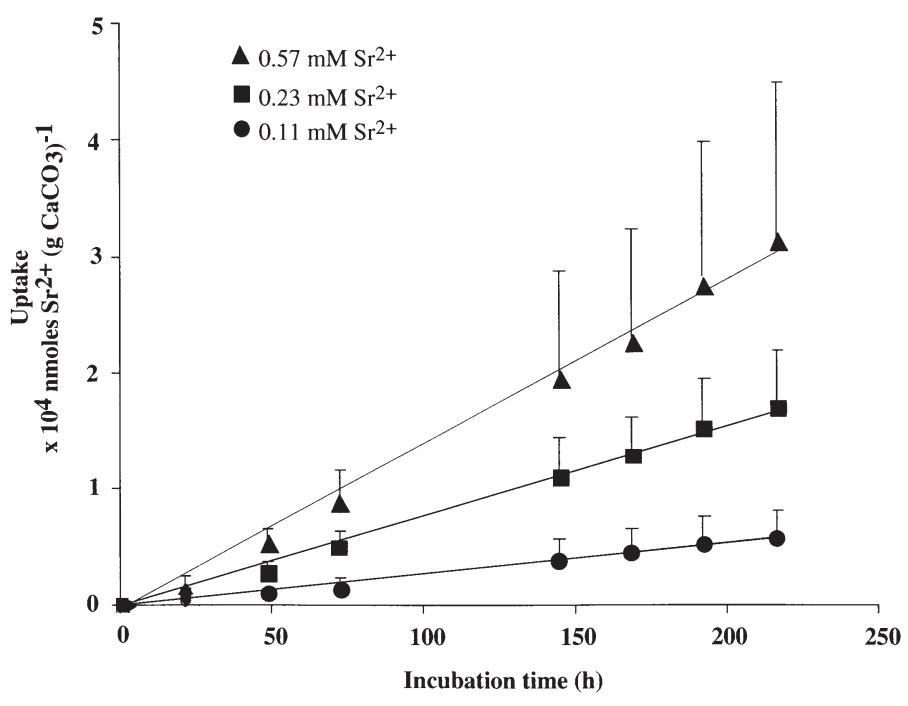

Fig. 1. $\mathrm{Sr}^{2+}$ incorporation in the whole colony over $9 \mathrm{~d}$ $\left(\times 10^{4} \mathrm{nmol} \mathrm{Sr}^{2+}\left[\mathrm{g} \mathrm{CaCO}_{3}\right]^{-1}\right)$. Uptake of $\mathrm{Sr}^{2+}$ in seawater at concentrations of $0.11(\mathbf{0}), 0.23(\mathbf{\square})$ and $0.57 \mathrm{mM}(\mathbf{\Delta})$. Data are presented as mean $+\mathrm{SD}(\mathrm{n}=5)$

$158.20 \mathrm{nmol} \mathrm{Sr}{ }^{2+}$ incorporated $\mathrm{gCaCO}_{3}^{-1} \mathrm{~h}^{-1}$, respectively (Fig. 1). Each correlation was highly significant. Radioactive $\mathrm{Sr}^{2+}$ was mostly incorporated into the skeleton and less than $1 \%$ was found in the tissue. In the following results, therefore, only the incorporation of $\mathrm{Sr}^{2+}$ in the skeleton will be presented. The amount of $\mathrm{Sr}^{2+}$ contained in the coelenteric cavity varied from

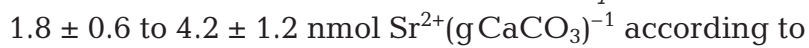
the $\mathrm{Sr}^{2+}$ concentration in seawater. The time needed to complete the efflux was calculated by measuring the amount of radioactivity released by corals in seawater

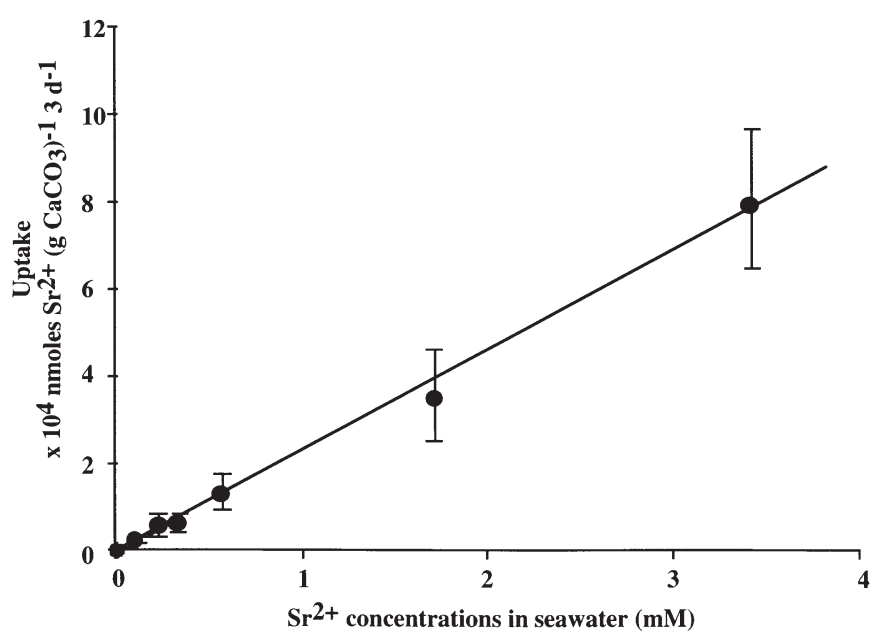

Fig. 2. $\mathrm{Sr}^{2+}$ incorporation in coral skeletons according to the $\mathrm{Sr}^{2+}$ concentration in seawater $(\mathrm{mM})$ measured after $3 \mathrm{~d}$ of incubation $\left(\times 10^{4} \mathrm{nmol} \mathrm{Sr}{ }^{2+}\left[\mathrm{g} \mathrm{CaCO}_{3}\right]^{-1} 3 \mathrm{~d}^{-1}\right]$. Data are presented as mean $+\mathrm{SD}(\mathrm{n}=10)$ versus time. It was found that the efflux was completed after between 20 and $30 \mathrm{~min}$.

The kinetics of $\mathrm{Sr}^{2+}$ uptake in the skeleton was followed when exposing 5 coral colonies over $3 \mathrm{~d}$ to increasing amounts of $\mathrm{Sr}^{2+}\left(0\right.$ to $300 \mathrm{mg} \mathrm{l}^{-1}$ or 0 to $3.42 \mathrm{mM}$ ) at normal $\mathrm{Ca}^{2+}$ concentration of seawater (Fig. 2). The same results were obtained when data were normalised per $g$ dry weight or per mg protein. Uptake rates (in the whole colony or in the skeleton) were linearly dependent upon the external concentration of $\mathrm{Sr}^{2+}$ and were equal to $88 \mu \mathrm{mol} \mathrm{Sr}^{2+}$ incorporated $\mathrm{g} \mathrm{CaCO}_{3}^{-1} \mathrm{~d}^{-1}$ and per mol external $\mathrm{Sr}^{2+}$.

To determine the mechanism of $\mathrm{Sr}^{2+}$ transport, the effect of Verapamil, a $\mathrm{Ca}^{2+}$ channel inhibitor, was tested. This drug inhibited $\mathrm{Sr}^{2+}$ incorporation into the skeleton. The dose response experiments (Fig. 3) showed that half inhibition $\left(\mathrm{I}_{\mathrm{c} 50}\right)$ was obtained for a Verapamil concentration of $12 \mu \mathrm{M}$.

The kinetics of $\mathrm{Sr}^{2+}$ uptake was followed when exposing the corals to a wide range of $\mathrm{Sr}^{2+}$ levels at different $\mathrm{Ca}^{2+}$ concentrations (Fig. 4). The uptake of $\mathrm{Sr}^{2+}$ at high concentrations (>1 mM) decreased with the increase in $\mathrm{Ca}^{2+}$ concentration in the experimental medium (Fig. 4). This trend was not apparent for natural $\mathrm{Sr}^{2+}$ concentrations (Fig. 4).

\section{DISCUSSION}

Calcification in corals has been a topic of interest for over 100 yr (Chalker 1976, Tambutté et al. 1996), but as yet, the processes involved are poorly understood. Most of the papers have related to $\mathrm{Ca}^{2+}$ uptake and few have explored the effects of $\mathrm{Sr}^{2+}$ on calcification (Chalker 1981, Ip \& Krishnaveni 1991, Wright \& Marshall 1991). It is however essential for paleontologists to understand calcification processes in corals because

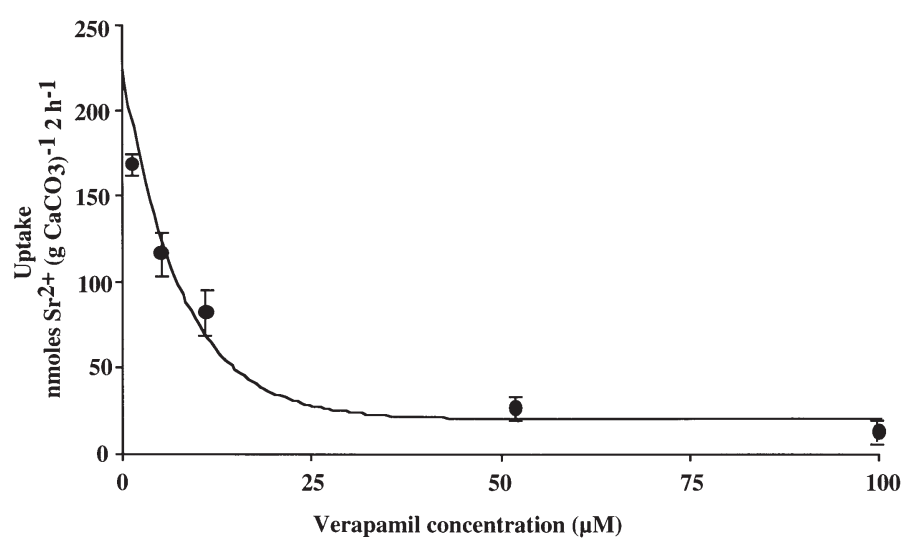

Fig. 3. $\mathrm{Sr}^{2+}$ incorporation in coral skeleton according to Verapamil concentrations $(\mu \mathrm{M})$ in seawater $\left(\mathrm{nmol} \mathrm{Sr} r^{2+}\left[\mathrm{g} \mathrm{CaCO}_{3}\right]^{-1} 2 \mathrm{~h}^{-1}\right)$. Data are presented as mean $+\mathrm{SD}(\mathrm{n}=3)$ 


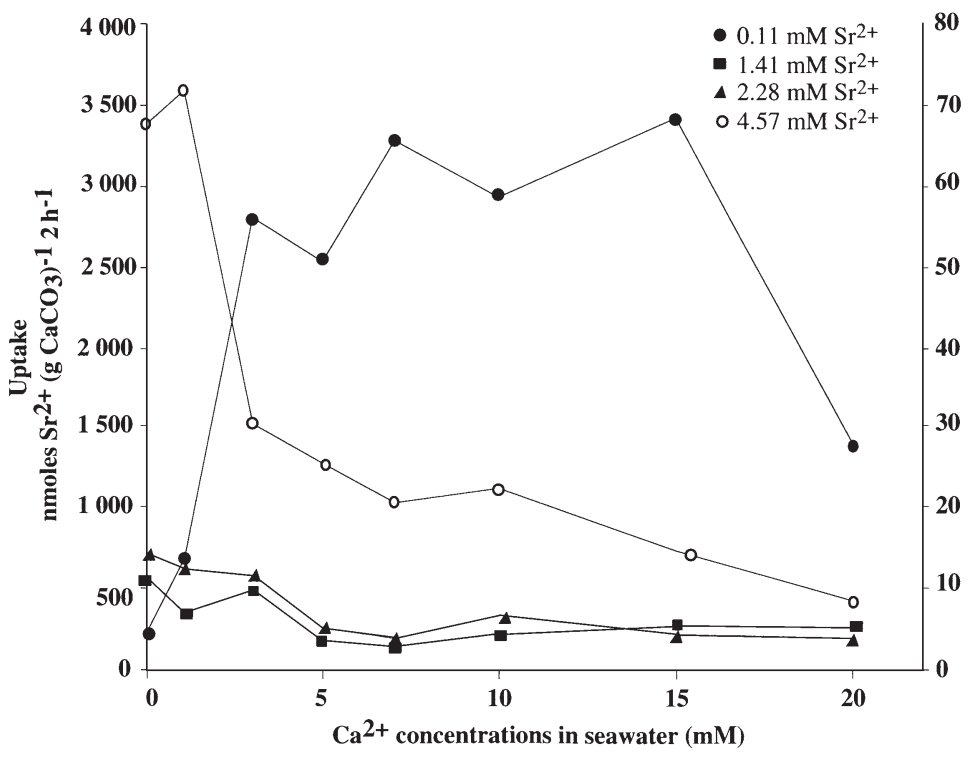

Fig. 4. $\mathrm{Sr}^{2+}$ incorporation at different $\mathrm{Sr}^{2+}(\mathrm{mM})$ and $\mathrm{Ca}^{2+}(\mathrm{mM})$ concentrations in seawater $\left(\mathrm{nmol} \mathrm{Sr}{ }^{2+}\left[\mathrm{g} \mathrm{CaCO}_{3}\right]^{-1} 2 \mathrm{~h}^{-1}\right)$. Right axis: uptake of $\mathrm{Sr}^{2+}$ in seawater at a concentration of $0.11 \mathrm{mM} \mathrm{Sr}^{2+}(\bullet)$. Left axis: Uptake of $\mathrm{Sr}^{2+}$ in seawater at concentrations of $1.41(\mathbf{\Xi}), 2.28(\mathbf{\Delta})$ and $4.57 \mathrm{mM} \mathrm{Sr}^{2+}(\mathrm{O})$. This figure represents the general pattern observed during 3 different experiments

the ratio of $\mathrm{Sr}^{2+} / \mathrm{Ca}^{2+}$ has been widely used to determine the temperature of the ancient seas (Swart 1981, Aharon 1991). Such determination is important since global climate is strongly influenced by the sea surface temperatures of the tropical oceans (Trenberth \& Hurell 1994).

Small coral colonies, prepared as described in Tambutté et al. (1995), were used for our experiments. The whole skeleton was entirely covered by animal tissue in order to avoid any contact with the external seawater containing the radioactive tracer. Therefore, nonspecific exchanges between radioactive and stable $\mathrm{Sr}^{2+}$ were avoided. For the first time, $\mathrm{Sr}^{2+}$ uptake was measured with a non-destructive method, which allowed us to follow its incorporation over $9 \mathrm{~d}$ in individual coral colonies. Experiments were performed with Stylophora pistillata, which is not a massive species, such as those commonly cored for paleoclimatic studies. The rates of calcification are of course different according to the coral species considered; however, the processes of calcification should be comparable in all corals. Moreover, microcolonies of $S$. pistillata were performed from 10 different parent colonies in order to assess the genetic variability.

By following the same nubbin over $9 d$, we found that $\mathrm{Sr}^{2+}$ uptake was linear as a function of time at different stable $\mathrm{Sr}^{2+}$ concentrations in seawater. Such linear uptake has already been observed for vertebrates
(Chowdhury et al. 2000), although for a shorter exposure time $(7 \mathrm{~h})$. This result is therefore one of the first showing linear uptake over several days for calcifying organisms such as corals. The rates of $\mathrm{Sr}^{2+}$ uptake measured in this study for $0.1 \mathrm{mM} \mathrm{Sr}^{2+}$ in seawater varied between 15 and $40 \mathrm{nmol} \mathrm{S \textrm {Sr } ^ { 2 + }} \mathrm{gskeleton}^{-1} \mathrm{~h}^{-1}$. They are in agreement with those found by Ip \& Krishnaveni (1991) at the same seawater concentration (9 to $15 \mathrm{nmol} \mathrm{Sr}^{2+}$ incorporated g skeleton ${ }^{-1}$ $\mathrm{h}^{-1}$ ). These rates are ca. 10 times lower than the rates of $\mathrm{Ca}^{2+}$ deposition in Stylophora pistillata, estimated to be equal to $550 \mathrm{nmol}{ }^{45} \mathrm{Ca}$ de-

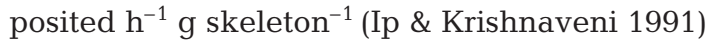
or $60 \mathrm{nmol}^{45} \mathrm{Ca}$ deposited $\mathrm{h}^{-1} \mathrm{mg}$ protein $^{-1}$ (Tambutté et al. 1996). $\mathrm{Ca}^{2+}$ concentrations in seawater are however 20 times higher than for $\mathrm{Sr}^{2+}$. This set of experiments also demonstrated the existence of a quick exchangeable $\mathrm{Sr}^{2+}$ compartment (efflux). This efflux corresponds to the washout of an extracellular compartment supposed to be the coelenteric cavity. The same conclusions were obtained for $\mathrm{Ca}^{2+}$ in scleractinian corals (Tambutté et al. 1996) and octocorals (Allemand \& Grillo 1992). The turnover rate of this compartment was estimated to be equal to $4 \mathrm{~min}$ in $S$. pistillata (Tambutté et al. 1995). The incorporation of $\mathrm{Ca}^{2+}$ in scleractinian corals has been shown to be saturable and therefore carriermediated (Chalker 1981, Tambutté et al. 1996), involving both passive and energy-requiring steps (Marshall 1996, Tambutté et al. 1996). Unlike $\mathrm{Ca}^{2+}$, the processes involved in the deposition of $\mathrm{Sr}^{2+}$ remain controversial as contradictory results have been reported. Kinsman (1969) was one of the first to suggest that the incorporation of $\mathrm{Sr}^{2+}$ was mediated by a diffusive pathway and that coral aragonite was in chemical equilibrium with seawater. Ip \& Krishnaveni (1991) and Ip \& Lim (1991) reached the same conclusion. Conversely, Goreau (1977) postulated that $\mathrm{Sr}^{2+}$ and $\mathrm{Ca}^{2+}$ were transported by the same ion carriers (active transport). This hypothesis was confirmed by the studies of Chalker (1981) and Wright \& Marshall (1991) who also suggested that $\mathrm{Sr}^{2+}$ was a competitive inhibitor of calcification, being transported to the sites of skeletogenesis by the same mechanisms. This conclusion was based on the observation that $\mathrm{Sr}^{2+}$ uptake was affected by the $\mathrm{Ca}^{2+}$ concentration in seawater.

The last set of experiments performed in the present work confirmed that $\mathrm{Sr}^{2+}$ uptake in corals depends on the $\mathrm{Ca}^{2+}$ concentration in seawater since $\mathrm{Sr}^{2+}$ uptake rates significantly decreased with an increase in $\mathrm{Ca}^{2+}$ concentration in seawater (Fig. 4). This result suggests that $\mathrm{Sr}^{2+}$ incorporation into the skeleton is inversely linked to the rate of calcification. Verapamil inhibits 
$\mathrm{Ca}^{2+}$ uptake through $\mathrm{Ca}^{2+}$ channels (Marshall 1996, Tambutté et al. 1996, Zoccola et al. 1999), thereby reducing the rate of calcification. This inhibitor, however, also reduced the rate of $\mathrm{Sr}^{2+}$ incorporation. Since this result cannot be interpreted as an effect mediated by the decrease in calcification (which would have stimulated $\mathrm{Sr}^{2+}$ incorporation), we can conclude that Verapamil exerts a direct effect on $\mathrm{Sr}^{2+}$ uptake. This result therefore strongly suggests a common pathway for $\mathrm{Ca}^{2+}$ and $\mathrm{Sr}^{2+}$ at the calicoblastic cell entry. This conclusion is strengthened by the similar $\mathrm{IC}_{50}$ measured for these 2 ions with Verapamil (ca. $12 \mu \mathrm{M}$; Tambutté et al 1996). We can therefore suggest that $\mathrm{Sr}^{2+}$ uses a transcellular transport pathway.

However, Fig. 3 showed that uptake of $\mathrm{Sr}^{2+}$ versus $\mathrm{Sr}^{2+}$ concentration did not display saturable Michaelis-Menten kinetics, as should have been the case if the incorporation of $\mathrm{Sr}^{2+}$ was carrier-mediated. The incorporation of $\mathrm{Ca}^{2+}$ and $\mathrm{Sr}^{2+}$ into the skeletal structures is a multi-step process, involving at least 5 steps: uptake by a $\mathrm{Ca}^{2+}$ channel at the cell membrane level, trans-cytotic transport (mediated either by $\mathrm{Ca}^{2+}$ binding proteins or by vesicle shuttle; cf. Johnston 1980, Bronner 1996), exit via a $\mathrm{Ca}^{2+}$-ATPase, binding to organic matrix macromolecules and precipitation with the carbonate moiety. The relationship between the rate of calcification versus ion concentration cannot therefore be interpreted as simple MichaelisMenten kinetics: a linear dependence between $\mathrm{Sr}^{2+}$ incorporation and $\mathrm{Sr}^{2+}$ concentration does not mean that a carrier-mediated step is not involved. Furthermore, the behaviour of $\mathrm{Sr}^{2+}$ may be different than that of $\mathrm{Ca}^{2+}$ for each of these different steps. For instance, while the permeation of $\mathrm{Sr}^{2+}$ through the $\mathrm{Ca}^{2+}$ channel of the jellyfish is higher than that of $\mathrm{Ca}^{2+}$ (Jeziorski et al. 1998), a lower permeation is generally reported in the literature (Estacion et al. 1999). Funamoto \& Mugiya (1998) also showed that $\mathrm{Sr}^{2+}$ affinity for the plasma protein in the goldfish Carassius auratus was 10 -fold lower than that of $\mathrm{Ca}^{2+}$. Finally, it has also been demonstrated that the affinity of the $\mathrm{Ca}^{2+}$ ATPase for $\mathrm{Sr}^{2+}$ was far lower than the affinity for $\mathrm{Ca}^{2+}$ (Yu \& Inesi 1995). Therefore, the whole process should adopt the kinetic parameters of the slowest step, thus explaining the linearity observed in the present study as well as that described by Ip \& Krishnaveni (1991). Nevertheless, the sensitivity of $\mathrm{Sr}^{2+}$ incorporation to Verapamil strongly suggests a common pathway (see above). The suggestion that $\mathrm{Ca}^{2+}$ and $\mathrm{Sr}^{2+}$ show different molecular behaviours is strengthened by the fact that the solubility of $\mathrm{Sr}^{2+}$ in seawater is at least 5 -fold lower than that of $\mathrm{Ca}^{2+}$. We were unable to increase the seawater $\mathrm{Sr}^{2+}$ concentration up to more than $5 \mathrm{mM}$ because of a strong precipitation of $\mathrm{SrCO}_{3}$ above this concentration.
In conclusion, we have demonstrated that the rate of $\mathrm{Sr}^{2+}$ strontium incorporation is constant for at least $9 \mathrm{~d}$. Incorporation of $\mathrm{Sr}^{2+}$ is inversely correlated to the rate of calcification, suggesting interaction between these 2 ions. Despite a linear correlation between $\mathrm{Sr}^{2+}$ incorporation and $\mathrm{Sr}^{2+}$ concentration (up to $3.4 \mathrm{mM}$ ), we suggest that $\mathrm{Sr}^{2+}$ uptake is mediated by a Verapamil-sensitive $\mathrm{Ca}^{2+}$ channel process. Consequently, $\mathrm{Sr}^{2+}$ incorporation into the skeleton should be biologically controlled by transcellular mediated steps. All these results should be taken into account before using $\mathrm{Sr}^{2+}$ in paleothermometry. Indeed, if the theory of Stoll \& Shrag (1998) is correct, i.e. the $\mathrm{Sr}^{2+}$ concentration of seawater varies over glacial-interglacial cycles, then the $\mathrm{Sr}^{2+}$ concentration in coral skeleton should also be affected and should change according to the external concentration. The $\mathrm{Sr}^{2+} / \mathrm{Ca}^{2+}$ ratio in molluscs was indeed found to be different between modern and ancient shells (Ragland et al. 1969). Moreover, the $\mathrm{Sr}^{2+} / \mathrm{Ca}^{2+}$ ratio in coral aragonite skeletons also seems more controlled by calcification processes than by temperature, even if these 2 parameters are closely linked. This conclusion is in agreement with the findings of Cohen et al. (2001) who used an ion microprobe technique. They demonstrated that the $\mathrm{Sr}^{2+} / \mathrm{Ca}^{2+}$ ratio in the symbiotic coral Porites lutea was more related to calcification rates than directly to seawater temperature. They showed that the $\mathrm{Sr}^{2+} / \mathrm{Ca}^{2+}$ content of the daytime skeleton was always lower than the adjacent nighttime skeleton. The enhancement of calcification in scleractinian corals by photosynthesis has been well documented, with light calcification being 3 to 4 times higher than dark calcification (Barnes \& Chalker 1988). According to our results, enhancement of calcification during the day should decrease the rate of $\mathrm{Sr}^{2+}$ incorporation, thereby explaining the decrease in the $\mathrm{Sr}^{2+} / \mathrm{Ca}^{2+}$ ratio observed by Cohen et al. (2001). Therefore, under in situ conditions, incorporation of $\mathrm{Sr}^{2+}$ should depend on both the coral calcification rate and seawater surface temperature. The same conclusion was reached for mollusc shells, where no correlation between the trace element and the isotope data was found (Leng \& Pearce 1999). This suggests that patterns of trace element variations cannot be only related to environmental factors, but that physiological factors affect the incorporation of trace elements into the shells (Leng \& Pearce 1999). The relative role of physiological and environmental controls in $\mathrm{Sr}^{2+}$ uptake remains to be determined.

Acknowledgements. We are grateful to Mr. J.-F. Comanducci for his significant contribution to the set-up and improvement of the nuclear detection system as well as to 3 anonymous reviewers. The Marine Environment Laboratory operates under an agreement between the International Atomic Energy Agency and the Government of the Principality of Monaco. 


\section{LITERATURE CITED}

Aharon P (1991) Recorders of reef environment histories: stable isotopes in corals, giant clams and calcareous algae. Coral Reefs 10:71-90

Alibert C, McCulloch MT (1997) Strontium/calcium ratios in modern Porites corals from the Great Barrier Reef as a proxy for sea surface temperature: calibration of the thermometer and monitoring the ENSO. Paleoceanography 12:345-363

Allemand D, Grillo MC (1992) Biocalcification mechanism in gorgonians: ${ }^{45} \mathrm{Ca}$ uptake and deposition by the Mediterranean red coral Corallium rubrum. J Exp Zool 262: $237-246$

Allemand D, De Renzis G, Ciapa B, Girard JP, Payan P (1984) Characterization of valine transport in sea urchin eggs. Biochim Biophys Acta 772:337-346

Allison N (1996) Comparative determinations of trace and minor elements in coral aragonite by ion microprobe analysis, with preliminary results from Phuket, southern Thailand. Geochim Cosmochim Acta 60:3452-3470

Barnes DJ, Chalker BE (1988) Calcification and photosynthesis in reef building corals and algae. In: Dubinsky Z (ed) Ecosystems of the world: coral reefs. Plenum Press, New York, p 109-131

Beck WE, Edwards RL, Ito E, Taylor FW, Recy J, Rougerie F, Joannot P, Henin C (1992) Sea-surface temperature from skeletal strontium/calcium ratios. Science 257:644-647

Boiseau M, Cornu H, Turpin L, Juillet-Leclerc A (1997) Sr/Ca and $\delta^{18} \mathrm{O}$ measured from Acropora nobilis and Porites lutea: is $\mathrm{Sr} / \mathrm{Ca}$ paleothermometry always reliable? $\mathrm{CR}$ Acad Sci 325:747-752

Bronner F (1996) Cytoplasmic transport of calcium and other inorganic ions. Comp Biochem Physiol 115B:313-317

Chalker BE (1976) Calcium transport during skeletogenesis in hermatypic corals. Comp Biochem Physiol 54:455-459

Chalker BE (1981) Skeletogenesis in scleractinian corals: the transport and deposition of strontium and calcium. In: Skoryna SC (ed) Handbook of stable strontium. Plenum Press, New York, p 47-63

Chowdhury MJ, Van Ginneken L, Blust R (2000) Kinetics of waterborne strontium uptake in the common carp, Cyprinus Carpio, at different calcium levels. Environ Toxicol Chem 19:622-630

Cohen AL, Layne GD, Hart SR, Lobel PS (2001) Kinetic control of skeletal Sr/Ca in a symbiotic coral: implications for the paleotemperature proxy. Paleoceanography 16(1):20-26

DeVilliers S, Shen GT, Nelson BK (1994) The Sr/Ca-temperature relationship in coralline aragonite: influence of variability in $(\mathrm{Sr} / \mathrm{Ca})_{\text {seawater }}$ and skeletal growth parameters. Geochim Cosmochim Acta 58:197-208

DeVilliers S, Nelson BK, Chivas AR (1995) Biological controls on coral $\mathrm{Sr} / \mathrm{Ca}$ and $\delta^{18} \mathrm{O}$ reconstructions of sea surface temperatures. Science 269:1247-1249

Druffel ERM (1997) Geochemistry of corals: proxies of past ocean chemistry, ocean circulation and climate. Proc Natl Acad Sci USA 94:8354-8361

Estacion M, Sinkins WG, Schilling WP (1999) Stimulation of Drosophila TrpL by capacitative $\mathrm{Ca}^{2+}$ entry. Biochem J 341(1):41-49

Evans M, Fairbanks RG, Rubenstone JL (1998) A proxy of ENSO teleconnections. Nature 394:732-733

Funamoto T, Mugiya Y (1998) Binding of strontium vs calcium in $17 \beta$-estradiol-induced proteins in the plasma of the goldfish, Carassius auratus. Fish Sci 64(2):325-328

Goreau TJ (1977) Coral skeletal chemistry: physiological and environmental regulation of stable isotopes and trace metals in Montastrea annularis. Proc R Soc Lond Ser B 196:291-315

Greegor RB, Pingitore NE Jr, Lytle FW (1997) Strontianite in coral skeletal aragonite. Science 275:1452-1454

Hart SR, Cohen AL (1996) An ion probe study of annual cycles of $\mathrm{Sr} / \mathrm{Ca}$ and other trace elements in corals. Geochim Cosmochim Acta 60:3075-3084

Hockett D, Ingram P, LeFurgey A (1997) Strontium and manganese uptake in the barnacle shell: electron probe microanalysis imaging to attain fine temporal resolution to biomineralization activity. Mar Environ Res 43:131-143

Horne RA (1969) Marine chemistry: the structure of water and the chemistry of hydrosphere. Wiley-Liss, New York

Hughen KA, Schrag DP, Jacobsen SB, Hantoro W (1999) El Niño during the last interglacial period recorded by a fossil coral from Indonesia. Geophys Res Lett 26:3129-3132

Ip YK, Krishnaveni P (1991) Incorporation of strontium $\left({ }^{90} \mathrm{Sr}^{2+}\right)$ into the skeleton of the hermatypic coral Galaxea fascicularis. J Exp Zool 258:273-276

Ip YK, Lim LL (1991) Are calcium and strontium transported by the same mechanism in the hermatypic coral Galaxea fascicularis? J Exp Biol 159:507-513

Jeziorski MC, Greenberg RM, Clark KS, Anderson PAV (1998) Cloning and functional expression of a voltagegated calcium channel alpha1 subunit from Jellyfish. J Biol Chem 273:22792-22799

Johnston IS (1980) The ultrastructure of skeletogenesis in zooxanthellate corals. Int Rev Cytol 67:171-214

Juillet-Leclerc A, Gattuso JP, Montaggioni LF, Pichon M (1997) Seasonal variation of primary productivity and skeletal $\delta^{13} \mathrm{C}$ and $\delta^{18} \mathrm{O}$ in the zooxanthellate scleractinian coral Acropora formosa. Mar Ecol Prog Ser 157:109-117

Kinsman DJJ (1969) Interpretation of strontium concentration in carbonate minerals and rocks. J Sediment Petrol 39: 486-508

Leng M, Pearce NJ (1999) Seasonal trace element and isotopic composition in a shell of a coastal mollusk, Mactra isabelleana. J Shellfish Res 18:569-574

Marshall AT (1996) Calcification in hermatypic and ahermatypic corals. Science 271:637-640

Matsunaga T, Ueno T, Amano H, Tkatchenko Y, Kovalyov A, Watanabe M, Onuma Y (1997) Characteristics of Chernobyl derived radionucleides in particulate form in surface waters in the exclusion zone around the Chernobyl Nuclear Power Plant. In: Fanghaenel T (ed) Migration '97. 6th Int Conf Chem Migration Behav of actinides and fission products in the geosphere, Vol 5. Elsevier, Amsterdam, p 101-113

McCullough MT, Gagan MK, Mortimer GE, Chivas AR, Isdale PJ (1994) A high resolution $\mathrm{Sr} / \mathrm{Ca}$ and $\delta^{18} \mathrm{O}$ coral record from the Great Barrier Reef, Australia and the 1982-1983 El-Niño. Geochim Cosmochim Acta 53:151-162

McCullough MT, Tudhope AW, Esat TM, Mortimer GE, Chappell J, Pillans B, Chivas AR, Omura A (1999) Coral record of equatorial sea-surface temperatures during the penultimate deglaciation at Huon Peninsula. Science 283: 202-204

Milliman JD (1974) Recent sediment carbonates. Part 1. Marine carbonates. Springer-Verlag, Berlin

Nichols DG, Scholz AT (1989) Concentrations of Cd, Sr, and U in fish and water samples collected from a small stream receiving uranium mine drainage. J Freshw Ecol 5:13-25

Noureddine A, Baggoura B (1997) Plutonium isotopes, ${ }^{137} \mathrm{Cs}$, ${ }^{90} \mathrm{Sr}$ and natural radioactivity in marine sediment from Ghazaouet (Algeria). J Environ Radioact 34:127-138

Olsgard F, Gray JS (1995) A comprehensive analysis of the effects of offshore oil and gas exploration and production 
on the benthic communities of the Norwegian continental shelf. Mar Ecol Prog Ser 122:277-306

Peck LS, Baker AC, Conway LZ (1996) Strontium labelling of the shell of the Antarctic limpet Nacella concinna (Strebel 1908). J Molluscan Stud 62:315-325

Ragland P, Pilkey OH, Blackwelder BW (1969) Comparison of the $\mathrm{Sr} / \mathrm{Ca}$ ratio of fossil and recent mollusc shells. Nature 224:1223-1224

Rosenthal Y, Boyle EA, Slowey N (1997) Temperature control on the incorporation of magnesium, strontium, fluorine and cadmium into benthic foraminiferal shells from Little Bahama Bank: prospects for thermocline paleoceanography. Geochim Cosmochim Acta 61:3633-3643

Spangenberg JV, Cherr GN (1996) Development effects of barium exposure in marine bivalve (Mytilus californianus). Environ Toxicol Chem 15:1769-1774

Speer JA (1983) Crystal chemistry and phase relations of orthorhombic carbonates. In: Reeder RJ (ed) Carbonates: mineralogy and chemistry. Mineralogical Society of America. Rev Mineral 11:145-190

Stoll HM, Shrag DP (1998) Effects of quaternary sea level cycles on strontium in seawater. Geochim Cosmochim Acta 62:1107-1118

Swart PK (1980) The effect of seawater chemistry on the growth rates of some scleractinian corals. In: Tardent $\mathrm{R}$, Tardent P (eds) Developmental and cellular biology of coelenterates. Proc 4th Int Coelenterate Symp, Interlaken. Elsevier, p 203-208

Swart PK (1981) The strontium, magnesium and sodium

Editorial responsibility: Otto Kinne (Editor), Oldendorf/Luhe, Germany composition of recent scleractinian coral skeletons as standards for paleoenvironmental analysis. Palaeogeogr Palaeoclimatol Palaeoecol 34:115-136

Tambutté E, Allemand D, Bourge I, Gattuso JP, Jaubert J (1995) An improved ${ }^{45} \mathrm{Ca}$ protocol for investigating physiological mechanisms in coral calcification. Mar Biol 122: 453-459

Tambutté E, Allemand D, Muller E, Jaubert J (1996) A compartmental approach to the mechanism of calcification in hermatypic corals. J Exp Biol 199:1029-1041

Trenberth KE, Hurrell JW (1994) Decadal atmosphere-ocean variations in the Pacific. Clim Dyn 9:303-319

Wansard G, Roca JR, Mezquita F (1999) Experimental determination of strontium and magnesium partitioning in calcite of the freshwater ostracod Herpetocypris intermedia. Arch Hydrobiol 145:237-253

Weber JN (1973) Incorporation of strontium into reef coral skeletal carbonate. Geochim Cosmochim Acta 37: 2173-2190

Wright OP, Marshall AT (1991) Calcium transport across the oral epithelium of scleractinian corals. Coral Reefs 10: $37-40$

Yu X, Inesi G (1995) Variable stoichiometric efficiency of $\mathrm{Ca}^{2+}$ and $\mathrm{Sr}^{2+}$ transport by the sracoplasmic reticulum ATPase. J Biol Chem 270(9):4361-4367

Zoccola D, Tambutté E, Senegas-Balas F, Michiels JF, Failla JP, Jaubert J, Allemand D (1999) Cloning of a calcium channel alpha1 subunit from the reef building coral Stylophora pistillata. Gene 227:157-167

Submitted: January 28, 2002; Accepted: August 19, 2002 Proofs received from author(s): November 21, 2002 